\title{
Peluang dan Tantangan Komersialisasi Biodisel-Review
}

\author{
Mahreni \\ Jurusan Teknik Kimia, Fakultas Teknologi Industri, \\ Universitas Pembangunan Nasional "Veteran" Yogyakarta \\ J1. SWK Lingkar Utara Condong Catur Yogyakarta, Indonesia (55283) \\ mahreni_03@yahoo.com
}

\begin{abstract}
Hydrogen is one of the environmentally friendly fuel, however hydrogen is not always available due to continuously increasing energy demand and fossil fuel availability become more limited. Gap between demand and supply is essential to find alternative fuels. Biodiesel could be a substituent for fossil fuels, especially for hydrogen. Biodiesel could be made by mixing vegetable oils or fats with fossil fuel with a ratio of (5-20) wt.\% however in a long time effect of this mixture can damage the engine. To overcome the problem, biodiesel can be synthesized via transesterification of oil and alcohol with the aid of acid or base catalyst to produce glycerol and FAME (Fatty Acid Methyl Ester). Challenges faced for the commercialization of biodiesel among others, (1) expensive raw material (edible oil), (2) reaction time and separation of the relatively long time (minimum 15 hours), (3) the use of acid catalysts still leaves the problem of corrosion and corrosion of machine tools and pollution to the environment by the catalyst. To make biodiesel competitive in the market, used oil (waste cooking oils, WCO), agricultural waste, and recent studies using microalgae could be used as source of biodiesel production. To shorten the reaction time, reaction was carried out using ultrasonic reactor technology and to minimize environmental pollution to use the solid catalyst. This paper will summarize on the adoption of latest technologies in producing biodiesel from used frying oil and microalgae.
\end{abstract}

Keywords: biodiesel, ultrasonic reactor, microalgae, alternative energi

\section{Pendahuluan.}

Saat ini dunia sangat bergantung kepada minyak bumi sebagai sumber energi. Kebutuhan energi dunia pada tahun 2008 mencapai 11.295 juta ton equivalen minyak bumi. Bahan bakar fosil (BBF) merupakan sumber energi utama di mana bahan bakar fosil memenuhi kebutuhan energi sebesar $88 \%$ keseluruhan sumber-energi. Bahan bakar fosil dipenuhi oleh $35 \%$ minyak bumi, $29 \%$ batubara dan $24 \%$ gas alam. Bahan bakar non fosil (BBNF) disuplai dari tenaga hidro $5 \%$ dan energi nuklir sebesar $6 \%$. Bahan bakar fosil merupakan penyumbang utama efek rumah kaca. Pada tahun 2006 emisi $\mathrm{CO}_{2}$ mencapai 29 giga ton dan diasumsi bahwa penyerapan $\mathrm{CO}_{2}$ hanya 12.000 giga ton selebihnya tidak dapat diserap dan ter-akumulasi di biosfera. Salah satu usaha untuk mengurangi emisi $\mathrm{CO}_{2}$ diadakan pertemuan Kyoto disebut The Kyoto Protocol pada tahun 1997. Dari pertemuan tersebut dan ketentuan yang ditetapkan dapat mengurangi emisi gas rumah kaca (green house gas) sebesar $5 \%$ sehingga usaha masih harus dilakukan dengan cara membangun teknologi yang dapat memanfaatkan $\mathrm{CO}_{2}$ sebagai bahan baku. Bahan bakar fosil juga merupakan sumber energi yang tak dapat diperbaharui. Sedikit yang membantah bahwa minyak bumi suatu saat akan habis dan kita terpaksa beralih ke jenis energi lainnya. Dampak ekonomi akibat ketergantungan terhadap BBF dapat dirasakan yaitu harga BBF naik secara eksponensial dengan waktu seperti digambarkan oleh Gambar 1. Sebagai contoh premium yang tahun 2004 harganya Rp $1.800 /$ liter naik hingga $\mathrm{Rp} 6.000 /$ liter pada tahun 2010.

Menemukan bahan bakar non fosil (BBNF) merupakan jalan keluar untuk mengurangi dampak negatif penggunaan BBF dan mengatasi kekurangan suplai bahan bakar. Biodisel merupakan BBNF yang dicadangkan menggantikan bahan bakar solar untuk mesin diesel karena beberapa keuntungan di antaranya berupa cairan, mudah disimpan dan didistribusikan, dapat menyamai kwalitas disel BBF dengan tanpa memodifikasi mesin disel. Oleh karena itu produksi biodisel berkembang dengan pesat. Hambatan komersialisasi dirasakan karena bahan bakunya adalah minyak makan, jagung dan tetes tebu relatif mahal sehingga perlu dicari bahan baku dari sumber lain yang murah agar biodisel dapat dikomersialisasikan. Untuk menurunkan harga biodisel dibutuhkan bahan baku yang lebih murah misalnya minyak goreng bekas, bahan baku limbah pertanian, minyak bekas dan laporan penelitian terbaru (Ayhan \& Fatih, 2010) melaporkan bahwa biodiesel dapat dibuat dari mikroalga. Minyak goreng bekas dapat diolah menjadi biodiesel melalui pengolahan pendahuluan sebelum reaksi transesterifikasi (Nadir et al, 2009). Mikroalga dapat diolah menjadi biodiesel melalui proses transesterifikasi seperti yang dilakukan pada minyak nabati. Mikroalga merupakan salah satu bahan baku biodiesel mempunyai dua keuntungan yaitu dapat 
mengeleminasi $\mathrm{CO}_{2}$ dan mengurangi ketergantungan terhadap BBF. Biodisel dari bahan baku mikroalga diharapkan di masa yang akan datang dapat menggantikan BBF. Kandungan minyak di-dalam mikroalga cukup tinggi dan mikroalga sangat mudah dibudidayakan. Mikroalga tumbuh pada lingkungan dengan kadar garam rendah sampai dengan kadar garam tinggi seperti di laut, danau dengan masa panen sangat singkat kurang dari 24 jam (Nadir et al, 2009). Mikroalga sangat menguntungkan sebagai bahan baku biodisel karena untuk luas lahan yang sama mikroalga menghasilkan minyak lebih banyak dibandingkan dengan sawit dan sumber lain.

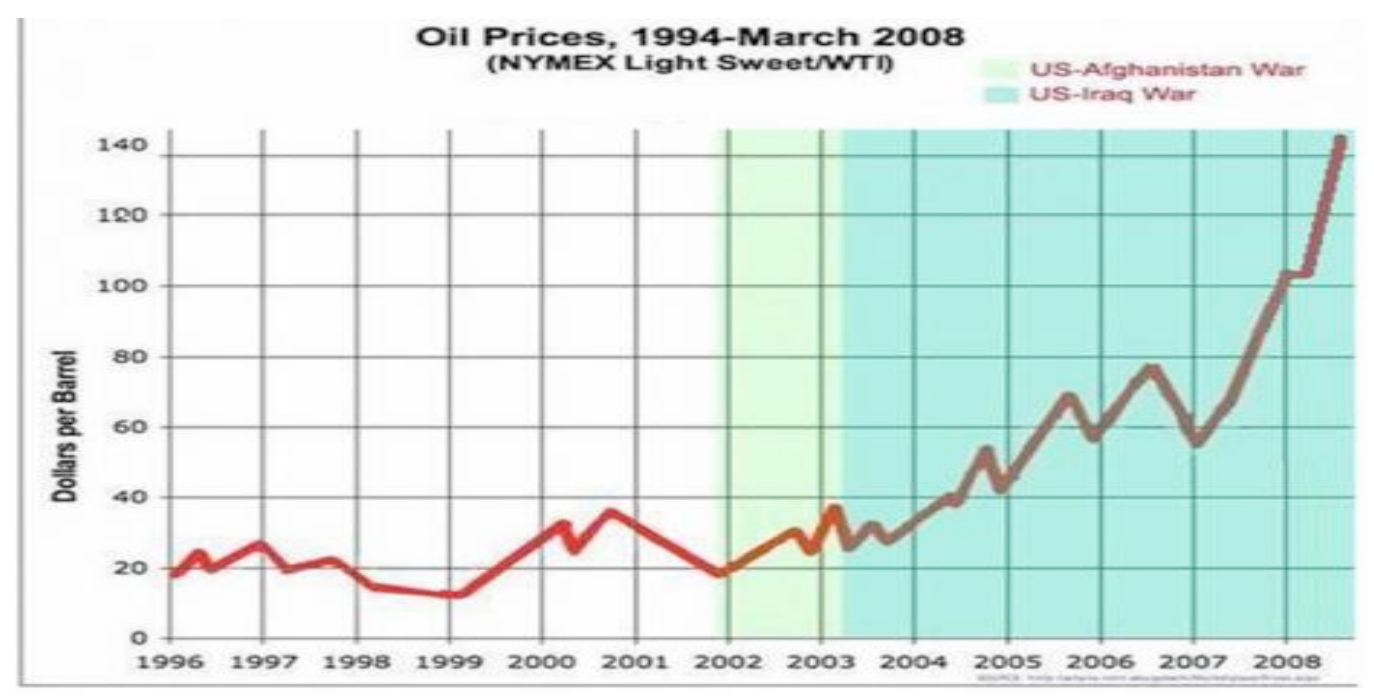

Gambar 1. Kenaikan harga minyak dunia dari tahun 1996 sampai dengan tahun 2008 [http://infoindonesia.wordpress.com/2009/05/25/apa-itu-neoliberalis].

Proses produksi biodiesel telah melalui tiga tahap ditinjau dari penggunaan bahan baku. Tahap pertama biodiesel diproduksi dari minyak makan (minyak sawit), tetes tebu, jagung dan minyak nabati lain. Disimpulkan bahwa biodiesel dari bahan makan tidak memberikan solusi terhadap usaha komersialisasi biodisel karena masyarakat harus berebut dengan pabrik yang memprodukasi biodisel. Generasi kedua biodisel dibuat dari limbah pertanian dan minyak nabati bekas (waste cooking oil, WCO). Limbah dan WCO cukup realistis untuk dijadikan sebagai bahan baku biodiesel karena biaya bahan baku menjadi kecil dan biaya persiapan (pretreatment) bahan baku menjadi salah satu faktor yang menentukan biaya produksi biodiesel. Generasi ketiga biodiesel diproduksi dari mikroalga (microalgae). Microalga sangat tepat dijadikan sebagai bahan baku biodiesel karena beberapa alasan yaitu: (1) dapat mengurangi $\mathrm{CO}_{2}$ di biosfera, (2) pertumbuhan sangat cepat dan (3) kandungan minyak tinggi, (4) dapat tumbuh pada lingkungan yang mempunyai kadar garam tinggi sehingga dapat dibudidayakan disepanjang pantai dan tidak mengurangi lahan pertanian. Biodisel dari mikro alga akan dibahas dalam makalah ini mengingat banyak keuntungan yang diperoleh apabila mikroalga dijadikan sebagai bahan baku biodiesel. Dalam makalah ini pembahasan akan difokuskan kepada produksi biodiesel dari dua sumber bahan baku minyak bekas dan mikroalga dengan tujuan untuk menghasilkan biodiesel yang dapat bersaing dengan BBF baik kawalitas maupun harga.

\section{Tinjauan Pustaka.}

\section{1. Proses Pembuatan Biodiesel dari Minyak bekas (Waste Cooking Oil, WCO).}

Minyak goreng bekas adalah minyak makan nabati yang telah digunakan untuk menggoreng dan biasanya dibuang setelah warna minyak berubah menjadi coklat tua. Proses pemanasan selama minyak digunakan merubah sifat fisika-kimia minyak. Pemanasan dapat mempercepat hidrolisis trigliserida dan meningkatkan kandungan asam lemak bebas (FFA) di dalam minyak [Nadir et al, 2009]. Kandungan FFA dan air di dalam minyak bekas berpengaruh negatif terhadap reaksi transesterifikasi. karena FAME dan gliserol menjadi susah untuk dipisahkan. Minyak goreng bekas lebih kental dibandingkan dengan minyak segar disebabkan oleh pembentukan dimer dan polimer asam dan gliserid di dalam minyak goreng bekas karena pemanasan sewaktu digunakan. Berat molekul dan angka iodin menurun sementara berat jenis dan angka penyabunan semakin tinggi (Enweremadu \& Mbarawa, 2009). 
Perbedaan komposisi asam di dalam minyak segar dan minyak goreng bekas dapat dilihat pada Tabel 1 . Tabel 1 menunjukkan bahwa kandungan hampir semua asam yang ada di dalam minyak goreng bekas lebih tinggi dibandingkan dengan di dalam minyak goreng segar (Nadir et al, 2009). Metode pembuatan biodisel dari mimyak goreng bekas tidak berbeda dengan proses pembuatan biodiesel dari minyak segar. Proses utama ialah reaksi transesterifikasi menggunakan katalis asam, basa atau enzim. Setiap jenis katalis mempunyai keuntungan dan kelemahan dalam reaksi transesterifikasi minyak bekas. Pemilihan katalis didasarkan kepada kandungan FFA dan air di dalam minyak. Proses transesterifikasi minyak bekas secara garis besar dilukiskan seperti pada Gambar 2 dibawah ini: (Enweremadu \& Mbarawa). Proses pembuatan biodsiel dari minyak bekas dapat dijelaskan sebagai berikut: Tahap pertama adalah pengolahan pendahuluan dengan cara menyaring minyak yang kotor kemudian memisahkan kotoran dari minyak. Untuk menurunkan kandungan air di dalam minyak goreng bekas caranya dengan mencampur minyak dengan zat pengering $\mathrm{CaCl}_{2}$. Kemudian dilewatkan melalui penyaring dengan filter selulosa untuk memisahkan kristal $\mathrm{CaCl}_{2}$ dan padatan koloid (Predojevic, 2009). Setelah minyak bebas dari partikel-partikel padat, kemudian menetralisasi asam lemak bebas (FFA) yang ada dalam minyak dengan menggunakan $\mathrm{KOH}$ atau $\mathrm{NaOH}$ atau basa lain. Proses netralisasi bertujuan untuk menurunkan kandungan FFA dan air di dalam minyak bekas. Kemungkinan pada proses netralisasi akan terbentuk sabun (padat) dan selanjutnya sabun dipisahkan dengan cara filtrasi.

Tahap kedua adalah reaksi transesterifikasi minyak bekas dengan methanol atau etanol dibantu oleh katalis. Katalis cair yang sering digunakan adalah $\mathrm{KOH}$ (basa) sedangkan dari golongan asam sering digunakan asam sulfat. Pada reaksi transesterifikasi minyak bekas, reaksi dilakukan melalui dua tahapp yaitu reaksi esterifikasi dengan menggunakan katalis asam dan tahap kedua adalah reaksi transesterifikasi dengan menggunakan katalis basa atau katalis padat [Pedojevic, 2009]. Pada tahap ketiga, FAME dan gliserol dipisahkan dengan cara dekantasi. FAME ada pada bagian atas dan gliserol pada bagian bawah bersama dengan katalis. Pemisahan kedua lapisan memerlukan waktu lebih dari 10 jam agar kedua lapisan dapat terpisah sempurna. Selanjutnya lapisan FAME dimurnikan dan disebut biodiesel.

Katalis padat yang sudah digunakan dalam reaksi transesterifikasi minyak bekas adalah $\mathrm{CaO}$, Nafion, Nafion- $\mathrm{SiO}_{2}, \mathrm{H}_{3} \mathrm{PW}_{12} \mathrm{O}_{40}$ (phosphotungstic acid) dan enzim [Enweremadu \& Mbarawa, 2009]. Hasil reaksi transesterifikasi adalah gliserol dan FAME. Reaksi transesterifikasi dilakukan pada kondisi suhu diatas suhu ruangan dan reaktor dilengkapi dengan pengaduk.

Proses pemanfaatan minyak sebagai bahan bakar bisa hanya dengan mencampur minyak nabati dengan BBF dengan persentase minyak nabati $5-20 \%$ berat. Tetapi campuran tersebut mengakibatkan kerusakan mesin yaitu umur mesin yang menggunakan bahan bakar campuran ini menunjukkan efek negatif apabila mesin dipakai dalam waktu lama. karena akan membentuk deposit karbon disebabkan oleh kekentalan minyak nabati jauh lebih tinggi dibandingkan dengan BBF (10-17 kali). Proses transesterifikasi dilakukan untuk menurunkan kekentalan minyak nabati sehingga tidak menjadi masalah pada pemompaan dan sifat fluidisasi (Demirbas, 2010).

Disamping itu minyak nabati menyebabkan deposit karbon dan pembentukan gel. Viskositas tinggi menyebabkan perubahan sifat fluida terutama apabila terjadi perubahan suhu yang besar seperti di daerah yang mempunyai empat musim. Pada suhu rendah minyak tidak dapat mengalir. Deposit karbon dipermukaan logam disebabkan oleh pembakaran tidak sempurna dan sifat penguapan lambat karena minyak nabati mengandung komponen trigliserida dengan berat molekul tinggi.

Lebih jauh mengapa minyak nabati tidak dapat langsung digunakan sebagai bahan bakar karena minyak nabati mengandung komponen-komponen asam lemak bebas, fosfolipid, sterol, air, komponen berbau dan bahan pengotor. Untuk mengatasi permasalahan tersebut, minyak nabati harus dimodifikasi dengan cara: (1) transesterifikasi, (2) pirolisis, (3) emulsifikasi [Meher et al, 2006]. Di antara tiga cara tersebut yang paling menguntungkan adalah transesterifikasi.

Transesterifikasi adalah reaksi alkoholisis minyak menghasilkan FAME dan gliserol. Emulsifikasi adalah mencampur minyak nabati dengan pelarut (alkohol) dengan perbandingantertentu sehingga membentuk emulsi. Pirolisis adalah perengkahan minyak menghasilkan bahan bakar bensin dengan bantuan panas. Pirolisis minyak nabati dapat menghasilkan bahan bakar lebih ringan dari minyak atau lemak tetapi kondisi reaksi memerlukan suhu dan tekanan tinggi sehingga mengkonsumsi banyak energi dan kurang efisien. Pada saat ini biodiesel diproduski dari minyak makan sehingga susah untuk dikomersialisasi. 
Tabel 1. Komposisi asam lemak di dalam minyak bunga matahari, minyak kedelai dan minyak bekas.

\begin{tabular}{llll}
\hline Asam lemak & Minyak Bunga Matahari & Minyak kedelai & Minyak bekas \\
\hline Lauric (12:0) & - & - & 9,95 \\
Myristic (14:0) & 0,06 & 0,07 & 0,19 \\
Palmitic (16:0) & 5,68 & 10,87 & 8,9 \\
Palmitoleic (16:0) & 0,14 & 0,10 & 0,22 \\
Searic (18:0) & 3,61 & 3,66 & 3,85 \\
Oleic (18:0) & 34,27 & 23,59 & 30,71 \\
Linoleic (18:2) & 54,79 & 53,86 & 54,35 \\
Linonelic (18:3) & 0,07 & 6,49 & 0,27 \\
Arachidic (20:0) & 0,25 & 0,37 & 0,29 \\
Gidoleic (20:1) & 0,13 & 0,22 & 0,18 \\
Bahenic (22:0) & 0,69 & 0,45 & 0,61 \\
\hline
\end{tabular}

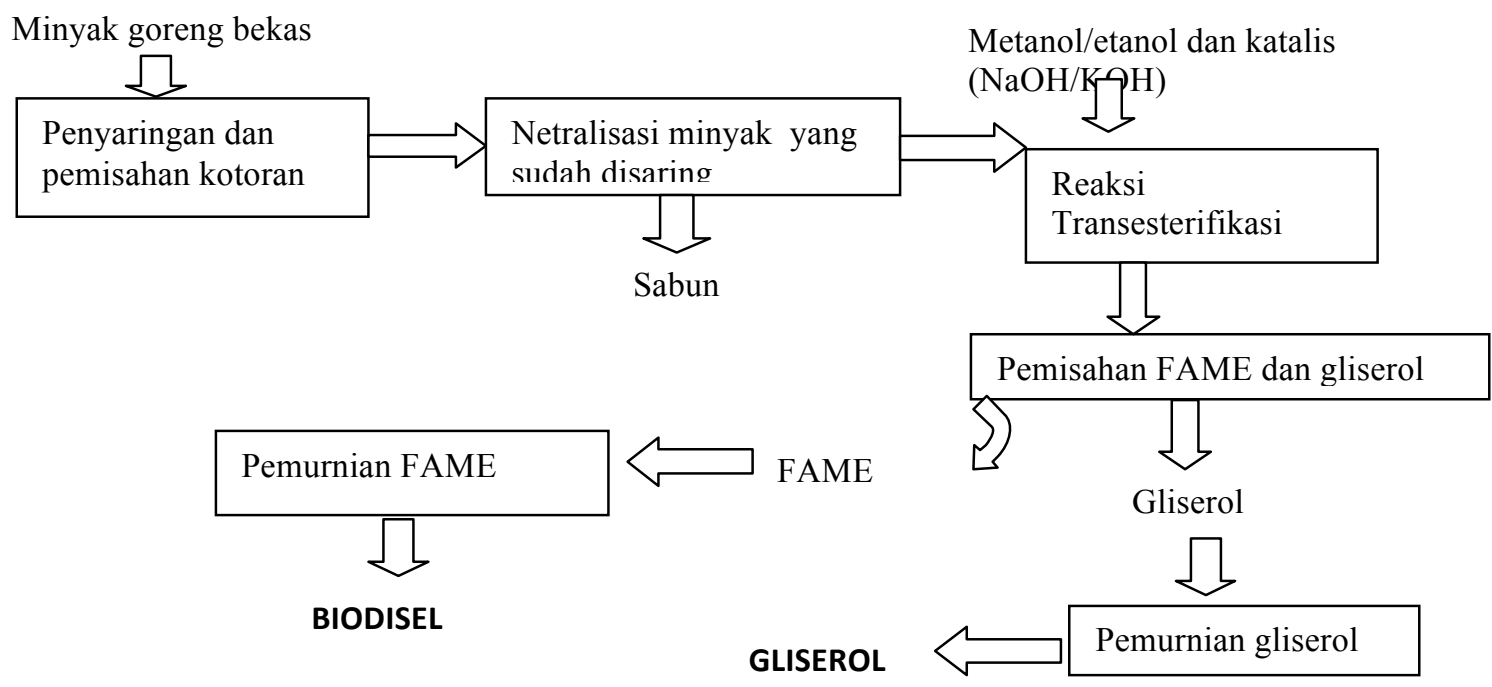

Gambar 2. Skema proses pengolahan minyak goreng bekas menjadi biodiesel.

Biodisel dari minyak segar dan biji-bijian dampaknya dapat mengurangi ketersediaan bahan pokok makanan dan harga biodiesel menjadi mahal. Masalah pemisahan dan waktu reaksi dapat diatasi dengan menggunakan katalisator padat dan menggunakan teknologi ultrasonik (Shakinaz et al, 2010) di mana dengan menggunakan teknologi ultra sonik, waktu reaksi dapat dipercepat dalam hitungan menit.

Kwalitas biodiesel harus memenuhi persyaratan yang ditentukan dan persyaratan yang harus dipenuhi oleh bahan bakar non fosil (BBNF) di antaranya adalah: (1) dapat dihasilkan dengan teknologi hemat energi dan ramah lingkungan, (2) ekonomis, (3) mudah didapat dan (5) sumber yang terbarukan dan berkesinambungan. Biodisel memenuhi persyaratan di atas karena beberapa alasan yaitu: (1) kandungan polutan (sulfur dan aromatik) rendah, (2) bisa didegradasi oleh mikroorganisma, (3) tidak beracun, (4) sumber BB dapat diperbaharui (Zlatica, 2008).

\subsection{Pengolahan pendahuluan minyak bekas sebagai bahan baku biodiesel}

Apabila minyak bekas akan dibuat biodiesel, memerlukan proses awal yang harus dilakukan dengan tujuan untuk mempermudah proses transesterifikasi. Tiga tahap harus dilakukan untuk mengolah minyak bekas menjadi biodiesel iaitu (1) pengolahan awal (penyaringan, adsorbs, pengeringan, netralisasi), (2) esterifikasi asam lemak bebas (Free Fatty Acid, FFA) dan (3) transesetrifikasi trigliserida (Triacylglyseride, TAG) dalam minyak menjadi FAME (biodiesel) dan gliserol. Dalam makalah ini hanya akan dibahas mengenai reaksi transesterifikasi. Proses pendahuluan telah dijelaskan pada bab 2. Selanjutnya langsung dijelaskan mengenai produksi biodiesel melalui reaksi transesterifikasi.

\subsection{Transestrifikasi.}

Transesterifikasi atau alkoholisis adalah reaksi menggantikan alkohol dari ester menjadi ester baru dan gliserol. Proses ini hampir sama dengan reaksi hidrolisis minyak. Pada reaksi alkoholisis molekul air diganti dengan alkohol. Apabila metanol yang digunakan disebut metanolisis, kalau etanol etanolisis dan seterusnya. Untuk mempercepat reaksi 
diperlukan katalis asam atau basa kuat

(Meher et al, 2006).

$$
\begin{array}{ll}
\mathbf{R C O O R}^{1}+\mathbf{R}^{2} \mathrm{OH} \stackrel{\text { katalis }}{\rightleftharpoons} & \mathrm{RCOOR}^{2}+\mathbf{R}^{1} \mathrm{OH} \\
\text { Ester (1) Alkohol (1) } & \text { Ester (2) Alkohol (2) }
\end{array}
$$

Gambar 3. Reaksi transesterifikasi secara umum.

\subsection{Kinetika reaksi transesterifikasi.}

Reaksi transesterifikasi adalah reaksi kesetimbangan. Transesterifikasi minyak nabati (trigliserida, TG) dan alkohol menghasilkan ester asam lemak (Free Acid Methyl Ester, FAME) dan gliserol (Demirbas \& Fatih, 2010). Karena reaksi kesetimbangan, maka untuk menggeser reaksi ke kanan memerlukan alkohol berlebihan. Selama reaksi terbentuk hasil antara ialah monogliserida (MG) dan digliserida (DG). Alkohol berlebihan mendorong reaksi ke kanan dan reaksi ke kanan menjadi reaksi orde satu semu dan reaksi ke kiri adalah orde dua. Reaksi transesterifikasi lebih cepat apabila menggunakan katalisator basa [Meher et al, 2006]. Persamaan reaksi transesterifikasi secara umum dapat dilihat pada Gambar 3 (Meher et al, 2006). Secara lengkap transesterifikasi minyak nabati dan alkohol digambarkan pada Gambar 4.

Mekanisme transesterifikasi pada suasana asam ditampilkan oleh Gambar 5 dapat dibagi menjadi tiga tahap yaitu: (1) protonasi gugus karbonil ester membentuk karbokation. (2) karbokation adalah senyawa antara yang reaktif dan kemudian menyerang molekul alkohol secara nukleofilik menghasilkan komponen hasil antara (intermediate product), (3) komponen intermediate mengeleminasi gliserol menghasilkan ester baru dan katalis (Meher et al 2010).

\subsection{Mekanisme reaksi transesterifikasi menggunakan katalis asam.}

Katalis asam lebih disukai di dalam asam sulfat. Menggunakan katalis asam sulfat menghasilkan metil ester lebih banyak dibandingkan dengan katalis lain tetapi reaksinya lambat (lebih dari tiga jam) dan suhu di atas $100^{\circ} \mathrm{C}$. Mekanisme reaksi dalam suasana asam dapat dilihat pada Gambar 5. (Meher et al 2010).
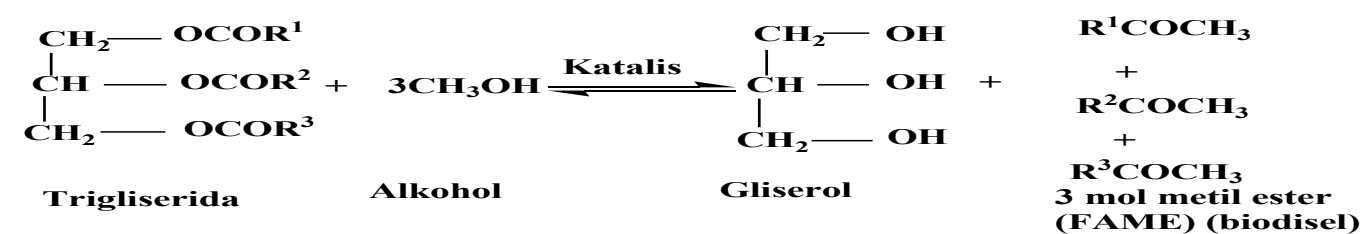

Gambar 4. Reaksi transesterifikasi minyak dengan alkohol

$$
\begin{aligned}
& \mathrm{R}^{1}-\stackrel{\mathrm{N}}{\mathrm{C}}-\mathrm{OR}^{2} \stackrel{\mathrm{H}^{+}}{\rightleftharpoons} \mathrm{R}^{1}-\stackrel{\mathrm{OH}^{+}}{\mathrm{C}}-\mathrm{OR}^{2} \leftrightarrow \mathrm{R}^{1}-\stackrel{\mathrm{N}}{\mathrm{C}}-\mathrm{OR}^{2}
\end{aligned}
$$

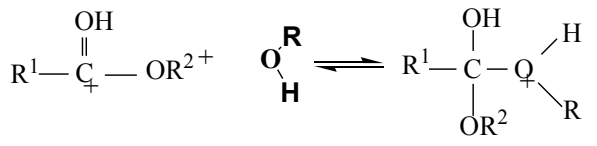

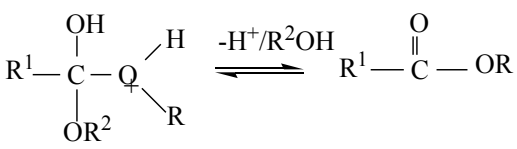

$$
\begin{aligned}
& \mathrm{R}=\text { alkil dari molekul alkohol } \\
& \mathrm{R}^{1}=\text { Rantai karbon asam lemak } \\
& \mathrm{R}^{2}=\text { Gliserida }
\end{aligned}
$$

Gambar 5. Mekanisme reaksi transesterifikasi menggunakan katalis asam.

\subsection{Mekanisme reaksi transesterifikasi \\ menggunakan katalis basa.}

Secara detail mekanisme reaksi transesterifikasi dalam suasana basa dapat dijelaskan melalui beberapa tahap: (1) sebelum reaksi berlangsung terjadi ikatan antara katalis dan trigliserida, (2) ion alkoksid menyerang karbon karbonil dari molekul trigliserida menghasilkan komponen hasil antara, (3) 
reaksi komponen hasil antara dengan molekul alkohol menghasilkan ion alkoksid, (4) penyusunan

Trigliserida $+\mathrm{R}^{1} \mathrm{OH} \rightleftharpoons$ Digliserida $+\mathrm{R}^{1} \mathrm{COOR}$

Digliserida $+\mathrm{R}^{1} \mathrm{OH} \rightleftharpoons$ Monogliserida $+\mathrm{R}^{1} \mathrm{COOR}$

Monogliserida $+\mathrm{R}^{1} \mathrm{OH} \rightleftharpoons$ Gliserol $+\mathrm{R}^{1} \mathrm{COOP}$

Gambar 6. Mekanisme reaksi tranesterifikasi dalam suasana basa

\subsection{Parameter yang berpengaruh terhadap reaksi transesterifikasi.}

Proses transesterifikasi dipengaruhi oleh beberapa faktor tergantung kondisi bahan baku. Beberapa faktor yang sangat berpengaruh terhadap reaksi transesterifikasi di antaranya adalah: (1) jenis asam lemak bebas, (2) kandungan asam lemak, (3) kandungan uap air di dalam minyak, (4) jenis katalis dan konsentrasi katalis, (5) perbandingan mol alkohol terhadap minyak dan jenis alkohol, (6) waktu reaksi dan temperatur, (7) kecepatan pengadukan dan (8) penggunaan Co-pelarut (Banerjee \& Chakraborty, 2009). Pengaruh beberapa parameter terhadap proses transesterifikasi dijelaskan lebih lanjut pada sub bab dibawah ini.

\subsubsection{Pengaruh jenis dan kandungan asam lemak bebas dan kandungan uap air dalam minyak.}

Kandungan dan jenis asam lemak bebas dan kandungan uap air di dalam minyak nabati, sangat menentukan keberhasilan reaksi transesterifikasi dari minyak nabati. Khusus katalis basa, kandungan asam kembali komponen hasil antara menghasilkan ester dan gliserol. lemak bebas dibatasi harus lebih kecil 3\% berat. Semakin tinggi kandungan asam lemak bebas, efesiensi konversi semakin rendah karena katalis basa akan bereaksi dengan asam lemak bebas membentuk sabun dan mengurangi alkil ester yang terbentuk. Selain itu sabun yang terbentuk menyebabkan pemisahan gliserol dan biodiesel (FAME) menjadi semakin sulit karena antara gliserol dan FAME membentuk emulsi.

\subsubsection{Jenis katalis dan konsentrasi katalis.}

Katalis yang digunakan untuk reaksi transesterifikasi trigliserida dapat diklasifikasikan menjadi katalis asam, basa, enzim dan katalis padat (heterogen). Katalis basa misalnya $\mathrm{NaOH}, \mathrm{KOH}, \mathrm{NaOCH}_{3}$ (Natrium metoksida) dan $\mathrm{KOCH}_{3}$ (kalium metoksida). Katalis asam misalnya asam kuat $\mathrm{H}_{2} \mathrm{SO}_{4}$, $\mathrm{HCl}$, asam fosfat, asam sulfonat organik. Katalis $\mathrm{NaOH}$ dan $\mathrm{NaOCH}_{3}$ digunakan sebagai katalis reaksi transesterifikasi dan aktivitas maksimum bisa dicapai berturut-turut dengan menggunakan perbandingan katalis:minyak $(0,3) \%$ berat dan $3 \%$ berat.

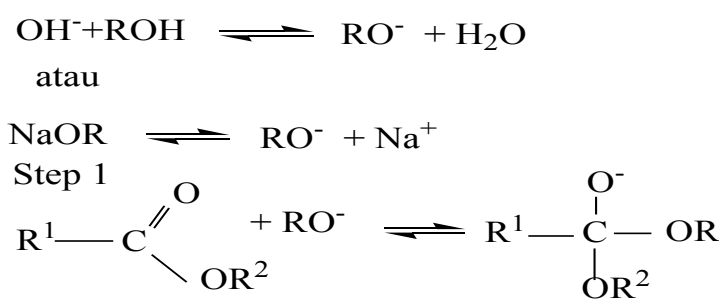

Step 2

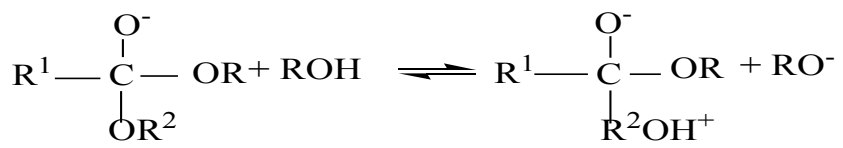

Step 3

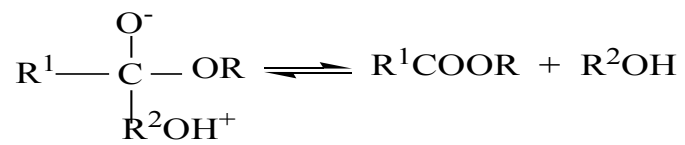

dimana $\mathrm{R}^{1}=$ Rantai karbon dari asam lemak<smiles>[R]CC(COC([R])=O)OC([R])=O</smiles>

Gambar 7. Mekanisme reaksi transesterifikasi dengan katalis basa. 
Tabel 2. Perbandingan Jenis Katalis Terhadap \% Hasil Biodisel

\begin{tabular}{|c|c|c|c|c|}
\hline Variabel & Katalis Basa & Katalis Asam & Katalis Enzim & Superkritik \\
\hline Temperatur & $60-70{ }^{\circ} \mathrm{C}$ & $55-80{ }^{\circ} \mathrm{C}$ & $30-40{ }^{\circ} \mathrm{C}$ & $239-385{ }^{\circ} \mathrm{C}$ \\
\hline $\begin{array}{l}\text { Konversi FFA } \\
\text { dalam bahan baku } \\
\text { dirubah menjadi }\end{array}$ & Sabun & Ester & Metil Ester & Ester \\
\hline $\begin{array}{l}\text { Efek Air terhadap } \\
\text { reaksi }\end{array}$ & Menginterferensi & Menginterferensi & Tidak berpengaruh & - \\
\hline \% Hasil (FAME) & Normal & Normal & Lebih tinggi & Di atas Normal \\
\hline Pmisahan Gliserol & Susah & Susah & Mudah & - \\
\hline Pemurnian FAME & Dicuci dengan air & Dicuci dengan air & Tidak usah dicuci & - \\
\hline Ongkos produkai & Murah & Murah & Mahal & Mahal \\
\hline
\end{tabular}

Katalis $\mathrm{NaOH}$ lebih baik dibandingkan dengan $\mathrm{NaOCH}_{3}$. Katalis Natrium metoksida menghasilkan hasil samping yang tidak diinginkan terutama garam natrium yang harus dipisahkan dan menjadi limbah. Katalis $\mathrm{NaOH} 1 \%$ berat dan $\mathrm{NaOCH}_{3} 0,5 \%$ berat dan perbandingan mol metanol:minyak 6:1 setelah 60 menit menghasilkan konversi yang sama. Usaha telah dilakukan untuk menggunakan logam alkali tanah pada reaksi transesterifikasi dengan menghadirkan metoksida di dalam media reaksi. Logam alkali tanah bisa dalam bentuk hidroksida, alkoksida, atau oksida. Reaksi berjalan lebih lambat karena hambatan difusi pada sistem reaksi tiga fasa (minyak-katalisalkohol).

Katalis $\mathrm{NaOH}$ menunjukkan aktivitas paling tinggi dibandingkan dengan alkali lainnya sebagai contoh dalam satu sistem reaksi minyak-alkohol konversi mencapai $85 \%$ setelah 30 menit dan mencapai 95\% setelah 1,5 jam. Barium hidroksida menunjukkan aktivitas lebih rendah dengan konversi $75 \%$ setelah 30 menit. Kalsium metoksida $\left(\mathrm{KOCH}_{3}\right)$ menunjukkan aktivitas cukup tinggi di mana konversi TG 55\% setelah reaksi berlangsung selama 30 menit, $80 \%$ setelah reaksi berlangsung selama 1 jam dan setelah 2,5 jam konversi 93\%. Kecepatan reaksi lebih lambat dibandingkan dengan katalis $\mathrm{CaO}$. Magnesium oksida $(\mathrm{MgO})$ dan $\mathrm{Ca}(\mathrm{OH})_{2}$ tidak menunjukkan aktivitas katalis pada reaksi transesterifikasi minyak. Untuk katalis asam yang paling baik adalah asam sulfat. Tetapi katalis asam menyisakan masalah pada saat biodiesel digunakan sebagai bahan bakar karena korosif. Walaupun katalis basa menghasilkan konversi tinggi dalam waktu lebih pendek tetapi hasil reaksi susah untuk dipisahkan karena membentuk emulsi. Asam dan basa juga akan menjadi limbah dan harus dipisahkan dari campuran hasil reaksi sehingga air buangan harus diolah sebelum dibuang ke lingkungan. Kelemahan kedua adalah asam lemak bebas dan air akan mempengaruhi konversi. Perbandingan jenis katalis terhadap produksi biodiesel dari minyak bekas secara transesterifikasi dapat dilihat pada Tabel 2. (Enweremadu \& Mbarawa, 2009).

Katalis enzim dapat menjadi jalan keluar untuk mengatasi kelemahan katalis asam dan basa dalam reaksi transesterifikasi trigliserida dalam sistem reaksi yang mengandung air atau tidak mengandung air seperti di dalam minyak bekas (WCO). Karena aktivitas enzim tidak terpengaruh oleh kandungan air dan asam di dalam minyak bekas. Dengan katalis enzim produk reaksi (gliserol) dapat dengan mudah dipisahkan dari campuran apabila minyak bekas digunakan sebagai bahan dasar biodiesel, katalis enzim tidak sensitif terhadap kandungan asam lemak bebas karena katalis enzim dapat mengkatalisis reaksi asam lemak bebas menjadi menjadi alkil ester. Di sisi lain harga enzim mahal sehingga akan meningkatkan harga jual biodiesel.

\subsubsection{Pengaruh perbandingan mol alkohol:minyak.} Salah satu parameter penting reaksi transesterifikasi minyak nabati adalah perbandingan mol alkohol:TG. Perbandingan mol stokiometrik alkohol:TG adalah 3:1. Setiap mol TG memerlukan 3 mol alkohol dan menghasilkan satu mol gliserol dan tiga mol FAME. Oleh karena reaksi transesetrifikasi adalah reaksi kesetimbangan, maka mol alkohol harus berlebihan agar reaksi berjalan ke kanan. Untuk menghasilkan konversi maksimum biasanya perbandingan mol alkohol:TG (6:1). Perbandingan mol tidak akan berpengaruh terhadap angka asam, peroksida, penyabunan dan iodin dari metil ester. Tetapi semakin besar perbandingan mol alkohol:TG akan menyulitkan pemisahan gliserol karena semakin banyak alkohol dalam campuran, gliserol semakin larut. Apabila gliserol tidak dipisahkan dari campuran hasil reaksi, memungkinkan reaksi akan bergeser kekiri dan menurunkan FAME yang dihasilkan. Satu penelitian menggunakan bahan dasar minyak (Cynara oil) dengan perbandingan etanol:TG divariasi dari 3:1 sampai dengan 15:1. FAME yang dihasilkan semakin besar dengan perbandingan etanol:TG semakain besar sampai dengan perbandingan etanol:TG (12:1). Hasil terbaik adalah pada perbandingan etanol:TG di antara $(9: 1$ dan 12:1). Apabila perbandingan mol etanol:TG $<6: 1$ reaksi tidak sempurna dan perbandingan etanol:TG (15:1) gliserol susah dipisahkan karen sebagian gliserol terlarut di dalam FAME. Oleh karena itu perbandingan mol etanol:TG terbaik adalah (9:1). Hasil penelitian yang telah dilakukan menunjukkan pengaruh jenis alkohol dan perbandingan mol 
alkohol: minyak bekas terhadap \% hasil dapat dilihat pada Tabel 3. (Enweremadu \& Mbarawa, 2009).

\subsubsection{Pengaruh kandungan air dan asam lemak bebas.}

Kandungan uap air dan asam lemak bebas di dalam minyak memegang peranan penting di dalam reaksi transesterifikasi. Penelitian yang dilakukan menyebutkan bahwa angka asam di dalam minyak harus lebih kecil dari 1\% berat. Apabila kandungan asam lemak bebas lebih besar dari $1 \%$ maka diperlukan jumlah katalis basa lebih banyak karena sebagian katalis akan digunakan untuk reaksi netralisasi asam lemak bebas (penyabunan). Juga apabila reaktan mengandung air, air yang ada akan membentuk sabun. Sabun yang terbentuk juga akan menaikkan viskositas campuran reaksi. Kadangkadang dapat membentuk gel dan pemisahan menjadi sulit menekankan kandungan asam lemak harus $(<0,5$ $\%$ berat) (Meher et al, 2010). Dapat disimpulkan bahwa baik kandungan asam lemak bebas, dan kandungan uap air harus dipertahankan pada batas minimal karena dapat menyebabkan deaktivasi katalis dan masalah pemisahan.

\subsection{Pengaruh pengadukan}

Pengadukan sangat diperlukan untuk membentuk campuran homogen dari dua cairan yang tidak saling melarutkan seperti minyak dan alkohol. Metanol dan etanol tidak larut dalam TG pada suhu ruangan reaksi transesterifikasi biasanya diaduk untuk memperbesar luas kontak reaktan dan memperkecil hambatan perpindahan masa. Selama reaksi berlangsung selalu membentuk emulsi. Pada proses metanolisis emulsi dengan cepat berubah menjadi lapisan yang kaya gliserol pada lapisan bawah dan lapisan metil ester pada lapisan atas. Apabila menggunakan etanol, emulsi lebih stabil dan pemisahan gliserol dan etil ester menjadi sulit. Pembentukan emulsi disebabkan oleh pembentukan komponen antara monogliserida dan digliserida yang mempunyai gugus polar (gugus hidroksil) dan gugus non polar (rantai hidrokarbon). Kedua intermediat adalah reagen penurun tegangan permukaan yang kuat. Pada proses alkoholisis, katalis $\mathrm{NaOH}$ atau $\mathrm{KOH}$ dapat larut di dalam fasa alkohol (polar) sementara TG tidak larut di dalam fasa alkohol. Pemisahan kedua lapisan FAME dan gliserol memerlukan waktu yang lama dan faktor kemudahan pemisahan antara FAME dan gliserol menjadi sangat menentukan efesiensi proses produksi biodiesel. Untuk mempercepat waktu pemisahan, maka produksi biodiesel diarahkan menggunakan katalis padat. Katalis padat mempunyai keunggunlan dibandingkan dengan katalis cair: (1) pemisahan cepat (beberapa menit), (2) katalis dapat digunakan kembali sehingga disamping dapat menghemat waktu juga dapat menghemat biaya katalis, (3) tidak menyebabkan korosi peralatan mesin.

\section{Usaha-usaha meningkatkan efeseinsi produksi biodiesel ditinjau dari segi teknik reaksi.}

Teknik produski biodiesel terfokus pada reaksi transesterifikasi. Kelemahan proses transesterifikasi secara konvensional adalah reaksi lambat, pemisahan lambat dan efek dari kedua masalah tersebut adalah harga jual biodiesel menjadi mahal dan merupakan hambatan komersialisasi biodiesel. Pada bab sebelumnya salah satu usaha menurunkan harga biodiesel adalah dengan menggunakan WCO atau mikroalga.

Tabel 3. Pengaruh jenis alkohol dan kondisi reaksi terhadap \% Hasil biodiesel

\begin{tabular}{|c|c|c|c|c|c|c|}
\hline Jenis alkohol & $\begin{array}{l}\text { Perbandingan } \\
\text { mol } \\
\text { alkohol:minyak }\end{array}$ & $\begin{array}{l}\text { Temperatur } \\
\left({ }^{\circ} \mathrm{C}\right)\end{array}$ & $\begin{array}{l}\text { Waktu } \\
\text { (jam) }\end{array}$ & Katalis & $\begin{array}{l}\text { \% Hasil (Waktu } \\
\text { pemisahan hasil } \\
2 \text { hari) }\end{array}$ & $\begin{array}{c}\% \text { Hasil } \\
\text { (Waktu } \\
\text { pemisahan } \\
\text { hasil } 7 \text { hari) }\end{array}$ \\
\hline Metanol & $3,6: 1$ & 65 & 40 & $0,1 \% \mathrm{H}_{2} \mathrm{SO}_{4}$ & 79,3 & 64 \\
\hline Metanol & $3,6: 1$ & 50 & 24 & $0,4 \% \mathrm{KOH}$ & 91,9 & 85,3 \\
\hline Etanol & $3,6: 1$ & 73 & 40 & $0,1 \% \mathrm{H}_{2} \mathrm{SO}_{4}$ & 66,9 & 54,8 \\
\hline Etanol & $3,6: 1$ & 50 & 24 & $0,4 \% \mathrm{KOH}$ & 28,9 & - \\
\hline 1-propanol & $3,5: 1$ & 90 & 40 & $0,1 \% \mathrm{H}_{2} \mathrm{SO}_{4}$ & 92,1 & 76,2 \\
\hline 1-propanol & $3,5: 1$ & 50 & 24 & $0,4 \% \mathrm{KOH}$ & 42,7 & - \\
\hline 2-propanol & $3,5: 1$ & 80 & 40 & $0,1 \% \mathrm{H}_{2} \mathrm{SO}_{4}$ & 78,7 & 54,4 \\
\hline 2-propanol & $3,5: 1$ & 50 & 24 & $0,4 \% \mathrm{KOH}$ & 51,2 & - \\
\hline 1-butanol & $3,6: 1$ & 105 & 40 & $0,1 \% \mathrm{H}_{2} \mathrm{SO}_{4}$ & 78,1 & 61,9 \\
\hline 1-butanol & $3,6: 1$ & 50 & 24 & $0,4 \% \mathrm{KOH}$ & 59,5 & - \\
\hline $\begin{array}{l}\text { 2-ethoxy } \\
\text { ethanol }\end{array}$ & $42,1: 1$ & 125 & 40 & $0,1 \% \mathrm{H}_{2} \mathrm{SO}_{4}$ & 53,5 & 39,2 \\
\hline $\begin{array}{l}\text { 2-ethoxy } \\
\text { ethanol }\end{array}$ & $42,1: 1$ & 50 & 24 & $0.4 \% \mathrm{KOH}$ & 37,0 & - \\
\hline
\end{tabular}


Mikroalga pada saat ini menjadi pusat perhatian banyak peneliti untuk mendapatkan biodisel dengan harga yang murah tetapi beberapa hambatan di dalam teknologi produksi biodiesel menggunakan mikroalga masih memerlukan penelitian lebih lanjut. Beberapa teknologi baru dalam memproduksi biodiesel telah diteliti diantaranya dengan menggunakan teknologi ultra sonik.

\subsection{Alga Sebagai Sumber Bahan Baku Baru untuk Produksi Biodiesel}

Alga adalah tumbuhan sel tunggal yang dapat hidup di dalam air dan alga yang digunakan sebagai bahan bakar diesel adalah alga hijau (green algae). Merupakan tanaman eukariot mempunyai sifat pertumbuhan sangat cepat. Pada kondisi yang sesuai alga hijau dapat berlipat dua dalam waktu kurang dari 24 jam. Keistimewaan lain alga hijau mempunyai kandungan lemak lebih besar dari 50\% (Liam Brenan et al, 2010). Pertumbuhan yang cepat dan kandungan lemak cukup tinggi merupakan alasan yang kuat untuk menjadikan alga hijau sebagai bahan baku pembuatan biodiesel. Apabila dibandingkan dengan minyak dari biji-bijian, kandungan minyak alga hijau lebih tinggi. Setiap hektar hanya dapat menghasilkan minyak kedelai kurang lebih $450 \mathrm{~L}, 1.200 \mathrm{~L}$ minyak canola dan $6.000 \mathrm{~L}$ minyak sawit. Sekarang bandingkan dengan alga hijau setiap hektar dapat menghasilkan $90.000 \mathrm{~L}$ (Dermibas \& Fatih, 2010). Proses produksi biodiesel dari alga dimulai dari produksi mikroalga. Produksi mikroalga memerlukan sinar matahari, karbon dioksida, air, nutrien (nitrat, zat besi, dan elemen lain dalam jumlah sedikit). Hampir separoh berat kering mikroalga terdiri dari unsur karbon. Temperatur pertumbuhan mikroalga sekitar 293 and 303K. Untuk mengekstrak minyak dari mikroalga telah dikenal tiga cara yaitu (1) penekanan (press), (2) ekstraksi menggunakan heksana sebagai pelarut dan (3) ekstraksi superkritik. Saat ini metode penekanan cukup berhasil untuk mendapatkan minyak sebesar 70-75\% dari mikroalga. Metode

\begin{tabular}{clc} 
ekstraksi & Mikroalga & Kandungan minyak ( \% Berat Kering) \\
\cline { 2 - 3 } pelarut bisa & Botryococcus braunii & $25-75$ \\
Tabel 4. & Chlorella spp. & $28-32$ \\
minyak & Crypthecodinium cohnii & 20 \\
& Cylindrotheca spp. & $16-37$ \\
& Dunaliella primolecta & 23 \\
& Isochrysis spp. & $25-33$ \\
& Monallanthus salina N & 20 \\
& Nannochloris spp. & $20-35$ \\
& Nannochloropsis spp. & $31-68$ \\
& Neochloris oleoabundans & $35-54$ \\
& Nitzschia spp. & $45-47$ \\
& Phaeodactylum tricornutum & $20-30$ \\
& Schizochytrium spp. & $50-77$ \\
& Tetraselmis sueica & $15-23$ \\
\hline
\end{tabular}

dilakukan karena harga pelarut heksana cukup murah. Metode superkritik menghasilkan minyak yang lebih tinggi kemurniannya tetapi konsumsi energi lebih tinggi dibandingkan dengan metode penekanan dan ekstraksi. Kandungan minyak dan asam lemak mikroalga bervariasi sesuai dengan kondisi pertumbuhan. Minyak dari mikroalga mengandung asam lemak jenuh dan tidak jenuh. Kandungan asam lemak di dalam minyak mikroalga terdiri dari $36 \%$ oleic $(18: 1)$, 15\% palmitic (16:0), $11 \%$ stearic (18:0), $8.4 \%$ iso- $17: 0$, and $7.4 \%$ linoleic (18:2). Proporsi asam lemak jenuh lebih besar dibandingkan dengan asam lemak tidak jenuh sehingga sangat sesuai untuk dijadikan bahan bakar biodiesel karena selama pembakaran, kemungkinan reaksi polimerisasi lebih kecil dibandingkan dengan apabila kandungan asam lemak tidak jenuhnya tinggi (Liam Brenan et al, 2010). Setelah minyaknya diekstrak, residu biomasa mikroalga dapat dijadikan untuk sumber protein. Kandungan minyak di dalam mikroalga dapat dilihat pada Tabel 4 dibawah ini:

\subsection{Produksi biodiesel dari minyak mikroalga.}

Proses produksi biodiesel dari mikroalga tidak berbeda dengan minyak nabati atau lemak. Empat tahap pada produksi biodiesel dari minyak atau lemak untuk memproduksi biodiesel dari mikroalga ialah pencampuran dengan BBF dengan persentase antara 5-20\% berat, emulsifikasi dengan alkohol, pirolisis dan transesterifikasi. Reaksi transesterifikasi paling banyak digunakan untuk menurunkan kekentalan minyak dari mikroalga. Diagram alir proses produksi biodiesel dari mikroalga ditampilkan pada Gambar 8 (Dermibas \& Fatih, 2010). 


\subsection{Teknologi Reaktor Ultra Sonik dalam Produksi Biodisel.}

Teknologi reaksi transesterifikasi menggunakan bantuan ultrasonik adalah teknologi terbaru dalam perkembangan produksi biodiesel. Ultrasonik dapat mempercepat reaksi transesetrifikasi dari beberapa jam menjadi beberapa menit bahkan detik. Reaksi dilakukan di dalam reaktor ultrabunyi (ultrasonic reactor) menggunakan frekwensi rendah $20 \mathrm{kHz}$ dan energi $1 \mathrm{~kW}$ melalui dua step reaksi transesterifikasi. Reaksi tahap pertama menggunakan perbandingan mol minyak:metanol $(1: 2,5)$ dan $0,7 \%$ berat katalis dan menghasilkan $81 \%$ FAME. Tahap kedua menggunakan perbandingan mol minyak:metanol $(1: 1,5)$ dan $0,3 \%$ katalis menghasilkan $91 \%$ FAME. Waktu reaksi sangat singkat hanya kurang lebih 1 menit tetapi waktu pemisahan masih memerlukan 15 jam. Biodisel yang dihasilkan memenuhi standar JIS K2390 dan EN 14212. Diagram produksi biodiesel menggunakan reaktor ultra sonik ditampilkan pada Gambar 10 (Shakinaz et al, 2010).

Adapun neraca masa dalam produksi biodiesel dapat dilihat pada Gambar 9 di bawah ini (Thanh et al, 2010).

Reaktor ultrasonik adalah reaktor yang dapat berperan ganda disamping berfungsi sebagai pengaduk juga dapat berperan sebagai reaktor karena efek kavitasi dari gelombang ultrasonik dapat meningkatkan tenaga aktivasi melekul-molekul yang bereaksi dan dapat mempercepat reaksi.

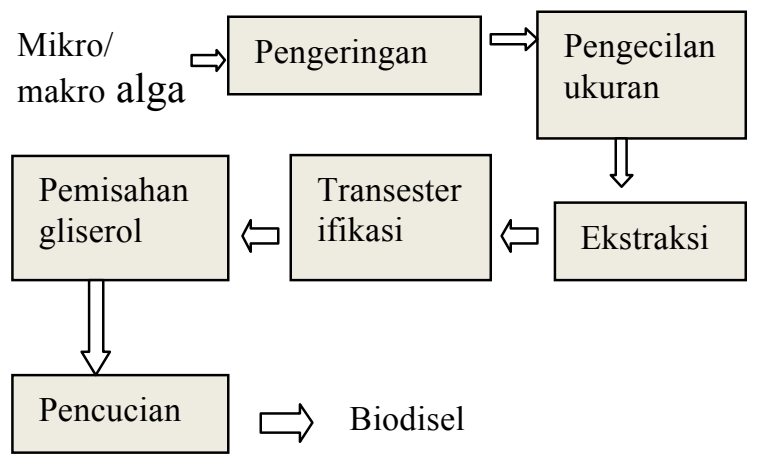

Gambar 8. Proses produksi biodiesel dari mikro alga

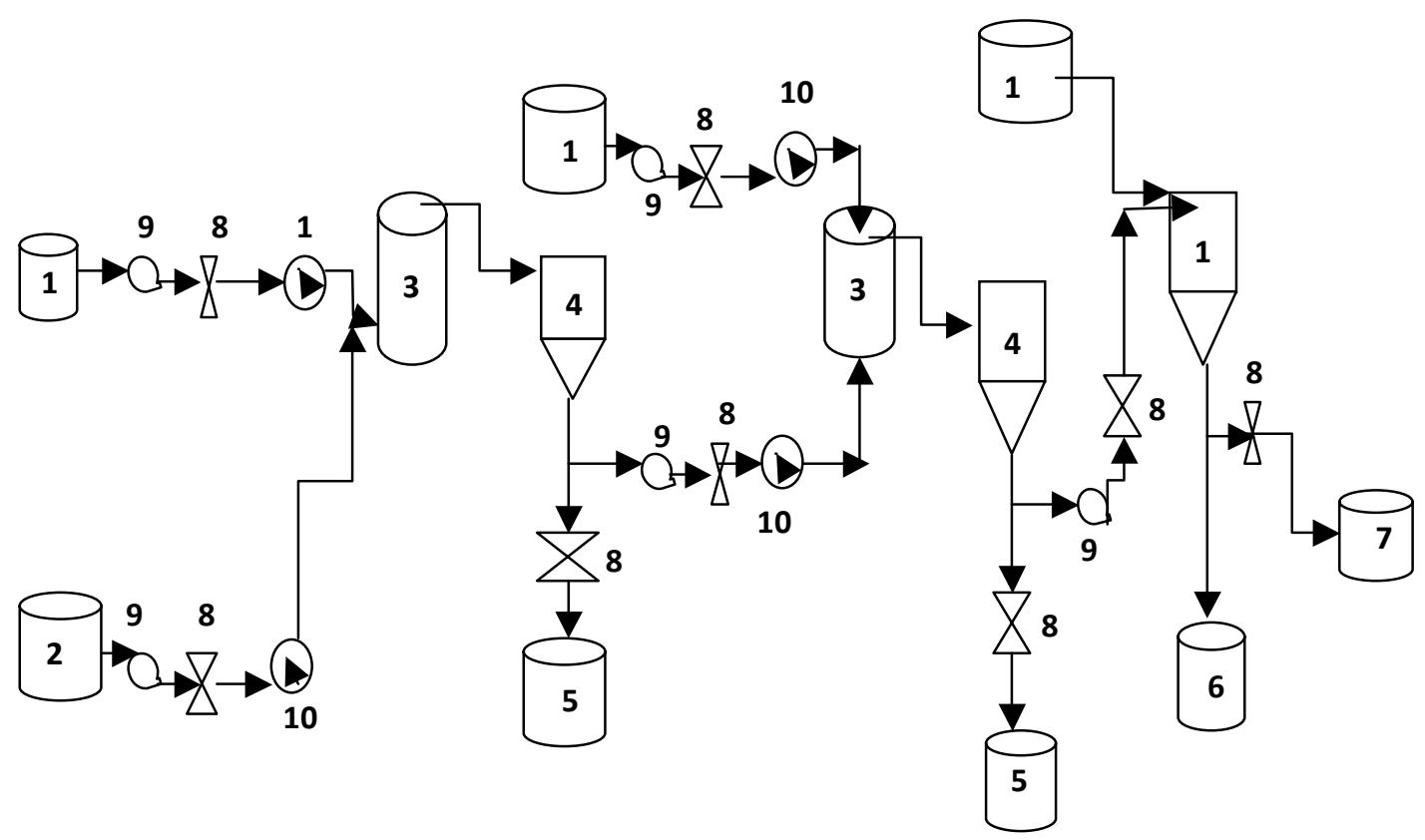


Gambar 9. Diagram alir produksi biodiesel menggunakan teknologi reaktor ultasonik: (1) Tangki metanol, (2) tangki minyak bekas, (3) reaktor ultrasonik, (4) tangki pemisah gliserol, (5) tangki gliserol, (6) tangki biodiesel, (7) tangki limbah, (8) kran, (9) pompa, (10) meter aliran, (11) tangki air pencuci dan (12) tangki pemurnian biodiesel

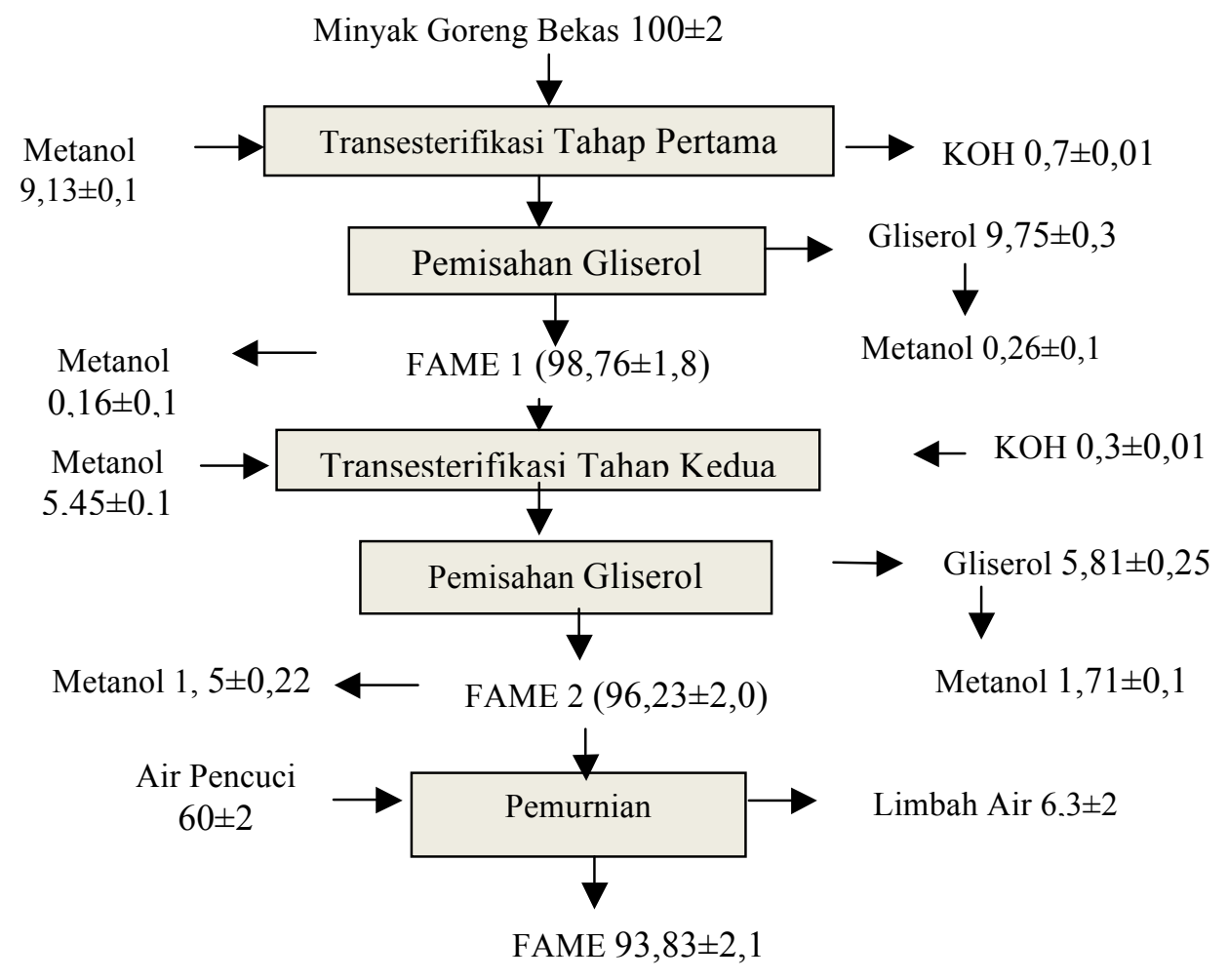

Gambar 10. Neraca masa produksi biodiesel dari minyak bekas menggunakan reaktor ultrasonik (Thanh et al, 2010).

Gambar 10 menunjukkan bahwa setiap 100 gram minyak bekas dan ditambah dengan 14, 6 gram metanol dapat menghasilkan 93,83 gram FAME dan gliserol 14,5 gram. Reaksi transesterifikasi dua step menggunakan reaktor ultrasonik sangat menguntungkan untuk memprodukai biodiesel dari minyak bekas. Kondisi optimal reaksi dicapai dengan perbandingan metanol: $\mathrm{WCO}=4: 1$, konsentrasi $\mathrm{KOH}$ $1 \%$ berat, waktu tinggal kurang lebih 1 menit untuk rekasi keseluruhan. Pada kondisi tersebut diperoleh konversi 93,8 \%. Kwalitas biodiesel diukur dengan metode JIS K2390 dan European committee standard (ENI 4214). Metanol yang digunakan lebih sedikit dibandingkan dengan metode konvensional (pengadukan mekanik dan superkritik) (Liu et al, 2009).

\section{Kesimpulan.}

Keuntungan utama biodiesel sebagai bahan bakar mesin diesel adalah (1) dapat diperbaharui, (2) kandungan sulfur dan senyawa aromatik rendah, (3) aman dalam penyimpanan dan distribusi dan (4) berbentuk cairan. Ke empat faktor tersebut merupakan peluang untuk mengembangkan biodiesel dengan tujuan untuk mengurangi emisi gas buang hasil pembakaran BB. Walaupun demikian sampai saat ini komersialisasi biodiesel masih mendapatkan hambatan terutama harga biodiesel lebih mahal dibandingkan BBF. Beberapa alternatif untuk memecahkan masalah komersialisasi ini yaitu (1) mengganti bahan baku biodiesel dari minyak makan dengan minyak bekas, limbah pertanian dan mikroalga. Bahan baku biodiesel dari mikro alga mempunyai kelebihan yaitu dapat mengurangi $\mathrm{CO}_{2}$ dan juga mengurangi ketergantungan akan BBF. Hambatan teknis dalam memproduksi biodiesel adalah proses transesterifikasi cukup lama (beberapa jam) pada suhu antara $40-120^{\circ} \mathrm{C}$. Untuk mengatasi waktu reaksi teknologi ultrasonik dapat menjadi jalan keluar karena waktu reaksi dapat dipercepat ratusan kali lebih cepat dibandingkan dengan menggunakan reaktor kovensioanl. Masalah lain adalah pemisahan hasil (gliserol dan FAME) memerlukan waktu yang cukup lama. Hal ini disebabkan oleh karena katalis yang digunakan adalah katalis homogen. Katalis homogen juga menyisakan masalah korosi dan limbah. Untuk mengatasi masalah pemisahan, sebaiknya menggunakan katalis padat (heterogen).

\section{Ucapan terimakasih.}


Terimakasih disampaikan kepada mahasiswa dibawah bimbinmgan saya yang telah melakukan penelitian dengan topik biodisel (Angga dkk) Tulisan

\section{Daftar Pustaka}

Ayhan Demirbas. 2005, Biodiesel production from vegetable oils via catalytic and non-catalytic supercritical methanol transesterification methods. Journal of Progress in Energi and Combustion Science 31, 466-487.

Ayhan, D \& F. Demirbas, M. 2008, Biodiesel from Algae di dalam Ayhan Demirbas \& Fatih Demirbas, M. Green Energi and Technology hlm. 139-144. Springer-Verlag London Limited

Banerjee, A \& Chakraborty R. 2009, Parametric sensitivity in transesterification of waste cooking oil for biodiesel production-A review. Journal of Resources, Conservation and Recycling 53, 490-497.

Enweremadu, C.C \& Mbarawa, M.M. 2009, Technical aspects of production and analysis of biodiesel from used cooking oil-A review. Journal of Renewable and Sustainable Energi Reviews 13, 2205-2224.

Le Tu Thanh., Kenji Okitsu ., Yasuhiro Sadanaga ., Norimichi Takenaka., Yasuaki Maeda., Hiroshi Bandow. 2010, A two-step continuous ultrasound assisted production of biodiesel fuel from waste cooking oils: A practical and economical approach to produce high quality biodiesel fuel. Journal of Bioresource Technology 101, 5394-5401

Liam Brennan and Philip Owende. 2010, Biofuels from microalgae- A review of technologies for ini. disusun dengan tujuan untuk menjawab sebagian masalah yang muncul selama penyusunan proposal.

production, processing, and extraction of biofuels and co-product. Journal of Renewable and Sustainable Energi Reviews 14, 557-577.

Meher, L.C., Vidya, D. \& Sagar, S.N. 2006, Naik.Technical aspects of biodiesel production by transesterification-a review. Journal of Renewable and Sustainable Energi Reviews 10, 248-268.

Nadir Dizge., Coskun Aydiner., Derya, Y. I., Mahmut Bayramoglu., Aziz Tanriseven Bulent Keskinler. 2009, Biodiesel production from sunflower, soybean, and waste cooking oils by transesterification using lipase immobilized onto a novel microporous polymer. Journal of Bioresource Technology 100, 1983-1991.

Shakinaz, A., El Sherbiny., Ahmed, A., Refaat., Shakinaz, T., El Sheltawy. 2010, Production of biodiesel using the microwave technique. Journal of Advanced Research Vol. 1, 309-314.

.Yun Liu., Hong-ling Xin., Yun-jun Yan. 2009, Physicochemical properties of stillingia oil: Feasibility for biodiesel production by enzyme transesterification. Journal of Industrial Crops and Products 30, 431-436.

Zlatica J. Predojevic. 2008, The production of biodiesel from waste frying oils: A comparison of different purification steps. Journal of Fuel $87,3522-3528$. 